ISSN: 2224-0616

Int. J . Agril. Res. Innov. \& Tech. 4 (1): 28-31, J une, 2014

Available online at http:/ / www.ijarit.webs.com

\title{
PHYSICAL, CHEMICAL AND MICROBIOLOGICAL ANALYSIS OF THE WATER QUALITY OF RAWAL LAKE, PAKISTAN
}

\author{
Mehreen Hassan* and Sana Hanif
}

Received 1 December 2013, Revised 26 May 2014, Accepted 28 June 2014, Published online 30 June 2014

\begin{abstract}
What better gift of nature would be than good quality water? In order to assess the quality of water of Rawal Lake, following research was carried out. Rawal lake is a source of drinking water supplied to many areas of Rawalpindi and Islamabad' the capital city of Pakistan. Water of this lake is being highly polluted by the local communities alongside the lake through solid waste dumping. Samples of surface water were collected, tested and analyzed in the laboratory on the basis of physical, chemical and microbiological parameters. The results showed uncertainties in many of the selected parameters. Microbiological analysis revealed high contamination of E. coli, fecal coliform and total coliform in the samples proving it unfit for drinking. It was found that the concentration of all physical parameters such as nitrates, chloride, $\mathrm{pH}$ and conductivity were within the normal limits. The level of heavy metals like lead, iron, chromium etc. was also found low. Turbidity at some points exceeded the maximum acceptable limit as per WHO statement.
\end{abstract}

Keywords: Water Quality, Rawal Lake, Water Contamination

Institute of Agricultural Sciences, University of the Punjab, Lahore, Pakistan

*Corresponding author's email: mehrinabbas@yahoo.com (Mehreen Hassan)

\section{Introduction}

The surface water and ground water quality is deteriorating day by day throughout the country. The discharge of industrial and domestic wastewater into open water bodies and groundwater is the main threat to the country's water reserves. The non implementation of legislative measures and standards is aggravating the situation resulting in further deterioration in water quality observed over the year. The issue is becoming very serious as open water-bodies; like lakes, rivers, and streams are being increasingly contaminated (Au, 1995; Jaffer and Saleem, 1987).

Rawal lake is an important source of water supply; surface water is pumped through shallow wells or deep tube wells/turbines. The total withdrawal of water from surface is estimated at 712 MAF (Mateen and Garstang, 2008). Water, during its passage through rivers and through the ground acquires various types of dissolved and suspended impurities and heavy metals.

Water quality is characterized in terms of its physical, chemical and biological composition. It is important to note that many of the physical properties, chemical and biological characteristics are inter-related (Marletta, 1986). The biological characteristics of water quality are of fundamental importance in the control of diseases caused by pathogenic organisms of human origin. The microorganisms found in surface and wastewater includes viruses, bacteria, fungi, algae, protozoans, plants and animals. The chemical constituents of wastewater are typically classified as inorganic and organic. Inorganic constituents of concern include nutrients, nonmetallic constituent, metals and gases (Marletta, 1986).

Rawal Lake is the main source of water supply for Rawalpindi city. It is situated in the capital territory of Islamabad. It is situated at N $33^{\circ} 41^{\prime}$ 47.18”, E 73 $08^{\prime} 07.64^{\prime \prime}$ and at an Elevation of $1728 \mathrm{ft}$ above sea level. The lake is located on Korang river and has a catchment area of 106 sq miles, which generates 84,000 cubic feet of water in an average rainfall year. There are four major streams and 43 small streams contributing to its storage. The total storage capacity is 47,500 acre feet. Live storage is 43,000 acre feet (Mateen and Garstang, 2008). There are many people living around Rawal lake and its contributing streams who dump a large amount of solid waste, sewage waste, organic and inorganic wastes in it. This sewage waste generates different types of bacteria and contaminates the water of the lake (Mateen and Garstang, 2008). The people who use this water for drinking purposes are extremely vulnerable to fatal diseases. Therefore, it is necessary to monitor and analyse the water quality on all parameters and prepare a management plan for ensuring the water quality up to WHO standards. This report is about the pollution and drinking water quality of Rawal lake compared with its sources and their possible prevention 
management plan. Major objectives of the study were:

- To assess the variation in drinking water quality of Rawal lake and its contribution to water sources.

- Creating awareness among the country about importance of potable water.

- To make recommendations for prevention of water pollution.

\section{Materials and Methods}

\section{Selected sampling sites}

Prior to field sampling and testing, a sampling plan for water and wastewater monitoring in the area was made. A reconnaissance survey for identification of sampling points was made as a part of environmental monitoring program. Following sites were selected for sample collection

Natural stream with sewage pollution 1: This is the stream coming from the Quaid-E-Azam University Islamabad which eventually enters in the lake. It has large amounts of solid waste and chemicals added from the laboratory of the university. Therefore, it was a point worth selecting for sampling.

Natural stream with sewage pollution 2: This stream carries a large amount of solid wastes, which is added to the lake water.

Lake resort area: This area has a large human interference. As hundreds of people visit daily. Solid waste is added in the lake. The oils discharged from the boats there also pollute the water.

Table 1. Physical, chemical and microbiological parameters studied in the experiment

\begin{tabular}{lll}
\hline Physical Parameters & Chemical Parameters & Microbiological Parameters \\
\hline Temperature & Chloride & Total coliform \\
pH & Fluoride & Fecal coliform \\
BOD & Iron & E.coli \\
COD & Chlorine & \\
TSS & Lead & \\
TDS & Mercury & \\
Conductivity & Manganese & \\
Turbidity & Nitrate & \\
Colour & Calcium & \\
Hardness & Carbonate & \\
& Sodium & \\
& Potassium & \\
\hline
\end{tabular}

\section{Results and Discussion}

Results showed that the physical parameters were within the permissible limits except in the values of turbidity, which is due to the presence of suspended matter such as silt clay, finely divided organic and inorganic matter. Some heavy metals like lead, cadmium, potassium etc. were detected but they were in very low concentrations. A few of them were below detectable limit. However, most of the trace elements lie within the permissible limit prescribed by WHO. Coliform bacteria were
Inlet of Korang River: It has a large population near it adding solid waste in it.

Drain/ sewage of Shahdara: A large number of livestock of the near town pollutes the water. selected for sampling because it has a large human and livestock interference.

Drain/ sewage of Satrameel/ Chattar: It carries a large amount of solid waste and livestock excreta.

Centre of the lake: This point was selected because it has least human and livestock interference and can be used for comparison of source and lake water.

The above mentioned points were then marked for coordinates with the help of GPS. Samples were collected manually according to method developed by the Chief Technical Advisor of PWP for examination of wastewater. GIS based map was developed and average coordinates were taken by using GPS (Garmin) receiver over the bridges at downstream positions and marked. In addition fixed points photographs were taken for the purpose of analysis. Sampling protocols were finalized and undertaken and were analysed in PCRWR laboratory, Islamabad. A detailed and thorough examination of the given map was made for the identification of suitable sampling points for surface water. Collected samples were kept in an ice box to prevent bacterial growth and were sent to the laboratory within 3-4 hours. Following parameters were tested
Drain/ sewage of Banigala: This point was also detected in very high amounts. The source of coliform bacteria is the sewage water dumping into the Rawal lake. There is a high concentration of sedimentation transported into the lake through Korang river because there is very less forest and vegetation, which promotes the weathering and erosion process. Locations of sampling points in Rawal lake are given in Table 2. All the samples were collected during April and May 2008. 
Table 2. Physical parameters for surface water analysis

\begin{tabular}{|c|c|c|c|c|c|c|c|c|}
\hline S. No. & Locations & Colour & Odour & $\begin{array}{l}\text { Turbidity } \\
\text { (NTU) }\end{array}$ & $\mathrm{pH}$ & $\begin{array}{c}\mathrm{EC} \\
(\mathrm{U} / \mathrm{cm})\end{array}$ & $\begin{array}{l}\text { Alkalinity } \\
\text { (ppm) }\end{array}$ & $\begin{array}{l}\text { Hardness } \\
\text { (ppm) }\end{array}$ \\
\hline 1 & $\begin{array}{l}\text { Permissible } \\
\text { limits/WHO limits }\end{array}$ & Colorless & UO & 5 & $6.5-8.5$ & NGVS & NGVS & 500 \\
\hline 2 & $\begin{array}{l}\text { Natural stream with } \\
\text { sewage pollution } 1\end{array}$ & Colorless & UO & 49.8 & 7.56 & 476 & 162 & 197 \\
\hline 3 & $\begin{array}{l}\text { Natural stream with } \\
\text { sewage pollution } 2\end{array}$ & Colorless & UO & 76 & 7.54 & 477 & 167 & 192 \\
\hline 4 & Inlet of Korang river & Colorless & $\mathrm{U} . \mathrm{O}$ & 4.4 & 8.5 & 442 & 209 & 226 \\
\hline 5 & Lake resort area & Colorless & U.O & 4.3 & 8.4 & 442 & 209 & 225 \\
\hline 6 & $\begin{array}{l}\text { Drain/ sewage of } \\
\text { shahdara }\end{array}$ & Colorless & UO & 14.7 & 7.70 & 650 & 267 & 302 \\
\hline 7 & $\begin{array}{l}\text { Drain/ sewage of } \\
\text { banigala }\end{array}$ & Colorless & UO & 13.9 & 8.60 & 442 & 147 & 167 \\
\hline 8 & $\begin{array}{l}\text { Drain/ sewage of } \\
\text { satrameel }\end{array}$ & Colorless & UO & 7.4 & 8.08 & 454 & 157 & 177 \\
\hline 9 & Centre of the lake & Colorless & U.O & 4.1 & 8.2 & 440 & 205 & 225 \\
\hline
\end{tabular}

U.O: Unobjectionable

NGVS: No Guideline Value Set

Table 3. Chemical parameters for surface water analysis

\begin{tabular}{|c|c|c|c|c|c|c|c|c|c|}
\hline Sl. No. & Locations & TSS & $\mathrm{Cl}^{-}$ & $\mathrm{SO}_{4}^{-}$ & $\mathrm{Ca}$ & $\mathrm{Mg}^{++}$ & $\mathrm{NO}^{3-}$ & COD & BOD \\
\hline 1 & $\begin{array}{l}\text { Natural stream with } \\
\text { sewage pollution } 1\end{array}$ & 88 & 12 & - & 45 & 21 & 0.7 & 07 & 18 \\
\hline 2 & $\begin{array}{l}\text { Natural stream with } \\
\text { sewage pollution } 2\end{array}$ & 95 & 12 & - & 45 & 19 & 0.8 & 10 & 21 \\
\hline 3 & Inlet of Korang river & 8.7 & 16 & 67 & 56 & 20 & 10 & 29 & 4 \\
\hline 4 & Lake resort area & - & 9.0 & 40 & 50 & 18 & 9 & 27 & 3 \\
\hline 5 & $\begin{array}{l}\text { Drain/ sewage of } \\
\text { shahdara }\end{array}$ & - & 9 & 82 & 89 & 19 & 2 & - & - \\
\hline 6 & $\begin{array}{l}\text { Drain/ sewage of } \\
\text { banigala }\end{array}$ & - & 14 & 72 & 37 & 18 & 0.6 & - & - \\
\hline 7 & $\begin{array}{l}\text { Drain/ sewage of } \\
\text { satrameel }\end{array}$ & BDL & 10 & - & 41 & 18 & 0.7 & BDL & 7 \\
\hline 8 & Centre of the lake & - & 12 & 63 & 54.3 & 18 & 9 & 26 & 2 \\
\hline
\end{tabular}

(All concentration is expressed in ppm.

BDL : below detectablelimit

TSS: Total suspended solids

COD: Chemical Oxygen Demand

BOD: Biochemical Oxygen Demand)

Table 4. Heavy metals parameters for surface water analysis

\begin{tabular}{|c|c|c|c|c|c|c|c|c|c|}
\hline Sl. No. & Locations & $\mathrm{Pb}$ & $\mathrm{Ar}$ & $\mathrm{Cr}$ & $\mathrm{Cu}^{++}$ & $\mathrm{Fe}$ & $\mathrm{Mg}^{++}$ & $\mathrm{Cd}$ & $\mathrm{K}^{++}$ \\
\hline 1 & $\begin{array}{l}\text { Natural stream with } \\
\text { sewage pollution } 1\end{array}$ & 0.56 & - & - & - & $\mathrm{BDL}$ & 21 & - & 3 \\
\hline 2 & $\begin{array}{l}\text { Natural stream with } \\
\text { sewage pollution } 2\end{array}$ & 0.61 & - & - & - & 0.03 & 19 & - & 2.8 \\
\hline 3 & Inlet of Korang river & 0.09 & - & - & - & - & 0.02 & 0.03 & 2.99 \\
\hline 4 & Lake resort area & 0.08 & - & - & - & - & - & 0.03 & 2.4 \\
\hline 5 & $\begin{array}{l}\text { Drain/ sewage of } \\
\text { shahdara }\end{array}$ & - & - & - & - & - & 19 & - & 4.3 \\
\hline 6 & $\begin{array}{l}\text { Drain/ sewage of } \\
\text { banigala }\end{array}$ & - & - & - & - & - & 18 & - & 3.6 \\
\hline 7 & $\begin{array}{l}\text { Drain/ sewage of } \\
\text { satrameel }\end{array}$ & 0.69 & - & - & - & 0.04 & 18 & - & 2.4 \\
\hline 8 & Centre of the lake & 0.07 & - & - & - & 0.15 & - & - & 2.1 \\
\hline
\end{tabular}

All concentrations are expressed in ppm. 
Table 5. Microbiological parameters for surface water analysis

\begin{tabular}{|c|c|c|c|c|c|}
\hline S.No. & Locations & $\begin{array}{l}\text { Fecal coliform } \\
\text { MPN/ 100ml }\end{array}$ & $\begin{array}{l}\text { Total coliform } \\
\text { MPN/ 100ml }\end{array}$ & E. coli +ve/-ve & $\begin{array}{l}\text { Total plate } \\
\text { count at } 35^{\circ} \mathrm{C} \\
\mathrm{CFU} / \mathrm{ml}\end{array}$ \\
\hline 1 & $\begin{array}{l}\text { Natural stream with } \\
\text { sewage pollution } 1\end{array}$ & $>1600$ & $>1600$ & tve & - \\
\hline 2 & $\begin{array}{l}\text { Natural stream with } \\
\text { sewage pollution } 2\end{array}$ & $>1600$ & $>1600$ & tve & - \\
\hline 3 & Inlet of Korang river & $>1600$ & $>1600$ & +ve & - \\
\hline 4 & Lake resort area & $>1600$ & $>1600$ & tve & - \\
\hline 5 & $\begin{array}{l}\text { Drain/ sewage of } \\
\text { shahdara }\end{array}$ & 240 & 240 & tve & - \\
\hline 6 & $\begin{array}{l}\text { Drain/ sewage of } \\
\text { banigala }\end{array}$ & $>1600$ & $>1600$ & tve & - \\
\hline 7 & $\begin{array}{l}\text { Drain/ sewage of } \\
\text { satrameel }\end{array}$ & $>1600$ & $>1600$ & tve & 356.5 \\
\hline 8 & Centre of the lake & $>1600$ & $>1600$ & +ve & - \\
\hline
\end{tabular}

Water samples, which were collected from different locations of Rawal lake and its source inlets contain a high amount of bacterial contamination, which makes the water unhygienic for the drinking purposes and can cause water borne disease. So by following the pollution prevention management plan water could be made safer for drinking and other purposes.

Pollution level in the sources of lake water is slightly larger in case of heavy metals and chemical contamination. However, in the centre of the lake almost all of the physical parameters were within the permissible limits, which on the other hand are very high in the source streams. Therefore, it can be concluded that there is less contamination in the centre of the lake as compared to the sources where human interference is more.

So, after the complete monitoring and analysis of Rawal Lake water a management plan for the prevention of pollution can be made. By following this plan, we can minimize water pollution to a non hazardous level.

\section{Recommendations}

- Identify and plan for means to effectively protect and improve surface water quality.

- Prevent erosion and sedimentation of soil into surface water systems by increasing vegetation and growing more trees in the waterways.

- Environmental education should be necessary at grass root level. e.g curriculum \& syllabus.

- The government should enforce Pakistan environmental protection act properly.
- Stop deforestation by enforcing law and proper monitoring of forestry.

- There should be an alternative way to put sewage water, rather to put into the Rawal lake water. e.g. there should be seperate sewage treatment plants.

- A focal point organization must be identified to monitor the progress of the implementation of recommendations and their effect on overall water availability for drinking and other purposes. So, the progress can be monitored and any desired precautionary steps could be taken to protect our water resources.

\section{References}

$\mathrm{Au}$, E. 1995. EIA Follow Up and Monitoring. EIA Process Strengthening Workshop, Canberra. pp. 222-225.

Jaffer, M. and Saleem, M. 1987. Concentration of selected toxic trace metals in some vegetables and fruits of local origin. Pak. J . Agric. Sci. 24: 140-146.

Marletta, G.P. 1986. Determination of cadmium in roadside grapes. J. Sci. food Agric. 37: 1090-1096.

Mateen, H.A. and Garstang, R. 2008. Environmental Monitoring of Natural Streams/Nullahs in Sector F-7, Islamabad: Detailed analytical baseline report of surface water a research report submitted to the Ministry of Environment's Pakistan Wetlands Programme. p. 16. 